\title{
Effect of nurse crops and seeding rate on the persistence, productivity and nutritive value of sainfoin in a cereal-based production system
}

\author{
Harun Cicek $^{1,2}$ (D) | Serkan Ates ${ }^{2,3}$ (D) | Gazi Ozcan ${ }^{4}$ | Mehmet Tezel ${ }^{4}$ | Jennifer \\ G. Kling ${ }^{5}$ | Mounir Louhaichi ${ }^{2}$ (D) | Gurhan Keles ${ }^{6}$
}

${ }^{1}$ Research Institute of Organic Agriculture (FIBL), Frick, Switzerland

${ }^{2}$ International Centre for Agricultural Research in the Dry Areas (ICARDA), Amman, Jordan

${ }^{3}$ Department of Animal and Rangeland Sciences, Oregon State University, Corvallis, Oregon

${ }^{4}$ Bahri Dagdas International Agricultural Research Institute, Konya, Turkey

${ }^{5}$ Department of Crop and Soil Science, Oregon State University, Corvallis, Oregon

${ }^{6}$ Department of Animal Science, Adnan

Menderes University, Aydin, Turkey

\section{Correspondence}

Harun Cicek, Research Institute of Organic Agriculture (FIBL), Frick, Switzerland.

Email: harun.cicek@fibl.org

Funding information

Australian Centre for International Agricultural Research, Grant/Award Number: AH/2012/021

\begin{abstract}
Sainfoin (Onobrychis viciifolia Scop.) is one of the most drought-tolerant perennial legumes that can thrive in dry, alkaline soils. A 3-year study in the Central Anatolian Region of Turkey compared the persistence, productivity and nutritive value of sainfoin planted with nurse crops, namely Hungarian vetch (Vicia pannonica Crantz.) or triticale ( $\times$ Triticosecale Wittm, ex A. Camus), at three seeding rates. Sainfoin and nurse crop emergence were significantly affected by the companion nurse crop, sowing rate and establishment year. The number of sainfoin plants at emergence was lower during a drier "bad" year (110 plant $\left./ \mathrm{m}^{2}\right)$ than in a "good" precipitation year $\left(236 \mathrm{plant} / \mathrm{m}^{2}\right)$. Triticale had a more negative impact on sainfoin growth than vetch. Planting nurse crops at high seeding rates $(90 \mathrm{~kg} / \mathrm{ha}$ ) reduced the number of sainfoin seedlings as compared to the control, while the low seeding rate had little impact on sainfoin emergence. Planting sainfoin with triticale resulted in much greater yield exceeding $10 \mathrm{t} / \mathrm{ha}$, but reduced the forage nutritive value compared to sainfoin monocultures and sainfoin-vetch mixtures. The seeding rate of the nurse crops during a dry year did not affect DM yield in the year of establishment nor in the following year. The findings of this study indicate that planting sainfoin with a nurse crop can substantially increase the DM yield in the year of establishment without yield penalties in the subsequent years, despite fewer established plants, as compared to sainfoin monocultures.
\end{abstract}

\section{KEYWORDS}

Hungarian vetch, intercropping, low-input farming, seeding rate, triticale

\section{1 | INTRODUCTION}

Diversifying crop rotations with forage legumes is the key to reverse the land degradation and to enhance system productivity, profitability and environmental health (Davis, Hill, Chase, Johanns, \& Liebman, 2012; Entz et al., 2002; Gan et al., 2015). Despite these benefits, cultivation of forage legumes has been in decline in the Central and West Asia and North Africa (CWANA) region for the last decades (Ates, Feindel, Moneim, \& Ryan, 2014; Koohafkan \& Stewart, 2008; McIntyre, 2009). The underlying reasons for a reduction in forage legume cropping are diverse, ranging from improper agricultural policies and agronomic challenges to socio-cultural and economic aspects (Foyer et al., 2016; Porqueddu et al., 2016; Zander et al., 2016). A number of researchers in the region have investigated the potential for inclusion of annual forage cereals and legumes in cereal cropping systems (Annicchiarico et al., 2017; Christiansen et 
al., 2015; Larbi et al., 2010). However, perennial forage legumes have rarely been investigated in short-term crop rotations in CWANA's cereal-based systems (Annicchiarico, Barrett, Brummer, Julier, \& Marshall, 2015). In similar agro-ecological zones of Australia, such systems using lucerne (Medicago sativa L., alfalfa) and self-regenerating annual legumes in ley farming systems have been the basis of sustainable dryland cereal production (Bell, Moore, \& Kirkegaard, 2014; Norton \& Koetz, 2014).

Perennial forage legumes are important options for degraded production systems in CWANA. Considering the predicted climate change scenarios for this region, including higher temperatures and erratic precipitation, which will disproportionately affect this region, the need for broadly adapted legumes becomes crucial (IPCC, 2014). Considering these potentially harsh conditions, there is an urgent need for investing in development and management of locally adapted drought and heat-resistant legume cultivars, which can thrive in degraded soils (Ates, Norman, Ben Salem, Nutt, \& Cicek, 2015; Kölliker, Kempf, Malisch, \& Lüscher, 2017). Sainfoin (Onobrychis viciifolia Scop.) is one of the most drought-tolerant perennial legumes that can thrive in the dry, alkaline soils of the CWANA region (Irani, Majidi, Mirlohi, Karami, \& Zargar, 2015; Sölter, Hopkins, Sitzia, Goby, \& Greef, 2007). It is extensively grown in highland regions of West and Central Asia due to its tolerance to seasonally cold and hot climatic conditions (Sengul, 2003; Tufenkci, Erman, \& Sonmez, 2006). Sainfoin's resistance to alfalfa weevil, combined with its reduced risk of bloat for ruminants and secondary metabolites that improve protein utilization by ruminants, makes sainfoin an extremely attractive forage crop, particularly in low-input or organic livestock production systems (Wang, McAllister, \& Acharya, 2015). However, sainfoin cultivation can be challenging for farmers due to agronomic factors, such as poor competitive ability against weeds and nurse crops, inconsistent yields, lack of productive, locally available varieties and susceptibility to diseases (Häring et al., 2008; Kölliker et al., 2017; Moyer, 1985; Stevovic, Stanisavljevic, Djukic, \& Djurovic, 2012).

The agronomic performance and animal production potential of sainfoin have been widely documented in the literature (Kazuk, 2010; Küchenmeister, 2013; Liu, Lane, \& Davies, 2008; Malisch, Suter, Studer, \& Lüscher, 2017). Overall, low DM production in the year of establishment and poor persistence are the main limitations of sainfoin (Hanna, Kozub, \& Smoliak, 1977; Kölliker et al., 2017). Many researchers have investigated the companion crops in permanent pastures, using other forage grasses. Annual species are seldom considered, reflecting the fact that sainfoin is rarely investigated as a rotational crop in cereal-based systems (Liu et al., 2008). Selection of proper companion or nurse crops and better understanding of agronomy in regard to seeding rates of sainfoin and companion species are the keys to achieve a good forage stand with the required amount of sainfoin in the mixture (Malisch et al., 2017). Recent studies provide evidence that with the right selection of companion crops and seeding rates of these mixtures, sainfoin can be a very productive forage for low-input systems and significantly improve livestock performance (Häring et al., 2008).
Integration of sainfoin into cereal-based rotations entails using annual companion crops during the first year of establishment and achieving pure sainfoin stands in the second and/or third years. Ideally, the companion crops should be able to produce satisfactory amounts of forage DM and suppress weeds during the establishment year, without suppressing sainfoin establishment. When seeded as a pure stand in dry environments, sainfoin DM production ranges from 0.5 to $3 \mathrm{t} / \mathrm{ha}$, which is not sufficient to meet the forage demand for an average livestock producer (Jafari, Rasoli, Tabaei-Aghdaei, \& Salehi, 2014; Martiniello \& Ciola, 1994; Mikić et al., 2015). Using annual species such as barley and oat as a companion crop for lucerne establishment is a common practice in the North-western region of the USA (Chapko, Brinkman, \& Albrecht, 1991; Sheaffer, 1989), Australia (Norton \& Koetz, 2014) and in Balkan countries (Cupina et al., 2010). Annual legumes such as vetches and pea (Pisum sativum L.) are also used as a companion crops in red clover (Trifolium pratense L.) and lucerne establishment (Acar, Asci, Basaran, Ayan, \& Mut, 2011; Cupina et al., 2010; Mikić et al., 2015). Use of such annual legumes and cereals in sainfoin establishment is less common (Mikić et al., 2015).

An experiment was established to evaluate the effect of sowing sainfoin with Hungarian vetch (Vicia pannonica Crantz.) and triticale ( $\times$ Triticosecale Wittm. ex A. Camus.) (at three seeding rates) on establishment, persistence and subsequent dry-matter production. It was hypothesized that both nurse crops would increase the total forage production in the year of establishment, without compromising the persistence and subsequent production of sainfoin. It was also hypothesized that vetch and triticale would differ in their competitiveness against sainfoin, with triticale being more competitive than vetch, and that the interspecies competition would increase with increasing plant densities.

\section{2 | MATERIAL AND METHODS}

\subsection{Site and weather}

The experiments were conducted at Bahri Dagdas International Agricultural Research Institute $\left(37^{\circ} 51^{\prime} \mathrm{N}, 32^{\circ} 33^{\prime} \mathrm{E}, 1,008 \mathrm{~m}\right.$ above sea level), in Konya, Turkey. The soil at the site is a clay loam with alkaline characteristics. The site had an organic matter content of $2.2 \%$, high available P $250 \mathrm{~kg} / \mathrm{ha}$, Ca $446 \mathrm{~kg} / \mathrm{ha}$ and $\mathrm{K} 244 \mathrm{~kg} / \mathrm{ha}$, soluble salt $0.05 \mathrm{dS} / \mathrm{m}$, and a soil $\mathrm{pH}$ of 8.1. The experimental location has a highland, continental climate, characterized by low and highly erratic precipitation. Air temperatures and precipitation at the site during the experiment period (2014-2017) are given in Table 1. While total annual precipitation in the establishment year (2014/15) of Experiment 1 was similar to long-term means (LTM), during the establishment year (2015/16) of Experiment 2, precipitation was around $100 \mathrm{~mm}$ lower than the long-term average. The rainfall in autumn 2015 was highly erratic and $49 \%$ lower than the LTM. Low seasonal rainfall, particularly in the spring of $2015 / 16$, meant that the results from this year were representative for a drought year which 
TABLE 1 Establishment and sampling dates for Experiments 1 and 2

\begin{tabular}{|lllll} 
Experiment & $\begin{array}{l}\text { Establishment year } \\
\text { (seeding date) }\end{array}$ & $\begin{array}{l}\text { Seedling counts at } \\
\text { emergence }\end{array}$ & Harvests and plant number counts & $\begin{array}{l}\text { Completion of the } \\
\text { field studies }\end{array}$ \\
\hline Experiment 1 & November 2014 & December 2015 & June 2015, May 2016 and June 2017 & July 2017 \\
Experiment 2 & October 2015 & December 2016 & May 2016 and June 2017 & July 2017 \\
\hline
\end{tabular}

TAB LE 2 Monthly rainfall and mean daily air temperatures at Bahri Dagdas International Agricultural Research Institute, Konya, Turkey over three growing seasons

\begin{tabular}{|c|c|c|c|c|c|c|c|c|}
\hline Months & \multicolumn{3}{|c|}{ Air temperature $\left({ }^{\circ} \mathrm{C}\right)$} & LTM* & \multicolumn{3}{|c|}{ Rainfall (mm) } & LTM $^{*}$ \\
\hline September & 18.2 & 22.0 & 18.2 & 18.7 & 31.4 & 31.4 & 23.0 & 12.5 \\
\hline October & 12.2 & 14.5 & 14.1 & 12.6 & 37.0 & 39.0 & 0 & 29.9 \\
\hline November & 5.1 & 7.4 & 5.4 & 5.9 & 33.6 & 5.8 & 16.0 & 31.7 \\
\hline December & 4.4 & -1.0 & -2.0 & 1.3 & 18.6 & 2.6 & 16.4 & 42.0 \\
\hline February & 2.2 & 6.2 & -2.2 & 1.2 & 23.5 & 2.8 & 3.0 & 29.0 \\
\hline March & 6.0 & 7.8 & 6.9 & 5.8 & 53.8 & 37.8 & 98.0 & 28.4 \\
\hline April & 8.8 & 14.5 & 11.0 & 11.0 & 7.6 & 9.4 & 21.0 & 32.1 \\
\hline May & 16.1 & 15.9 & 15.4 & 15.8 & 53.2 & 35.2 & 41.0 & 43.5 \\
\hline
\end{tabular}

Note: LTM*: Long-term means of air temperature and rainfall are for the period 1975-2010. Data were collected from the meteorological station located nearby the experimental site.

occurs, on average, every 3 out of 10 years (Türkeş, Akgündüz, \& Demirörs, 2009). In most cases, the mean monthly air temperature was similar to the $\operatorname{LTM}\left(11.6^{\circ} \mathrm{C}\right)$

\section{2 | Establishment and experimental design}

Following cultivation and seedbed preparation, a monoculture of sainfoin (cv. Ozerbey) and binary mixtures of sainfoin with Hungarian vetch (cv. Tarm beyazi) or triticale (cv. Alperbey) were seeded with $0.2 \mathrm{~m}$ row spacing on $1.6 \times 5 \mathrm{~m}$ plots, using a plot seeder (Tarimoz, Eskisehir, Turkey) on 14 November 2014 (Establishment year 1/Experiment 1). Across all monoculture and mixture plots, the seeding rate of sainfoin (hulled seed) was kept constant at $100 \mathrm{~kg} / \mathrm{ha}$, while vetch and triticale were sown at seeding rates of 30,60 or $90 \mathrm{~kg} / \mathrm{ha}$ in the binary mixtures. The experiment was a randomized complete block design with seven treatments: sainfoin monoculture (control: sown at $100 \mathrm{~kg} / \mathrm{ha}$ seeding rate), and sainfoin-vetch and sainfoin-triticale mixtures, each sown at three seeding rates. Each of the seven treatments was replicated four times. The same treatments were imposed in an adjacent field on 30 October 2015 (Establishment year 2/ Experiment 2), to obtain two establishment years for inter-annual comparison. The seeding rate of sainfoin monoculture aimed to establish a target population of 300 plants $/ \mathrm{m}^{2}$, using seeds with a germination percentage of $85 \%$. In both years, fertilizer was applied at sowing at a rate of $36 \mathrm{~kg} \mathrm{~N} \mathrm{ha}^{-1}$ and $92 \mathrm{~kg} \mathrm{P} \mathrm{ha}^{-1}$. Weeds were mechanically removed through hand weeding at crop emergence in both years of establishment. No additional fertilizer or herbicide was applied during the experimental period. The experiment was carried out under rainfed conditions, without supplemental irrigation.

\section{3 | Sampling and measurements}

Seedling numbers of sainfoin, vetch and triticale were counted in two randomly placed $0.1 \mathrm{~m}^{2}$ quadrats after germination in December 2014 and 2015 in Experiments 1 and 2 respectively (Table 2). Plots were harvested at the full-bloom stage of sainfoin in early June 2015, late May 2016 and early June 2017. Plots were sampled only once in each growing season for dry-matter yield and nutritive value. Herbage production ( $\mathrm{kg} \mathrm{DM} \mathrm{ha}^{-1}$ ) was determined by cutting a random $0.25 \mathrm{~m}^{2}$ quadrat with electric shears to a stubble height of $50 \mathrm{~mm}$ in each plot. The herbage was sorted into botanical fractions (sainfoin, triticale, vetch and weeds) and then dried in a forcedair oven at $60^{\circ} \mathrm{C}$ for $48 \mathrm{hr}$ for DM determination. Only unsorted, bulk samples were subjected to the chemical analyses. Following 
collection of the samples, the remainder of the plots was mown to a stubble height of $50 \mathrm{~mm}$.

Following the harvest of the plots in each summer, the number of established sainfoin plants in both monoculture and mixture plots was counted in two randomly placed $0.1 \mathrm{~m}^{2}$ quadrats. Relative competition intensity $(\mathrm{RCl})$ for the established sainfoin plant density was calculated according to Grace (1995) using the following formula: $\mathrm{RCl}=\left(P_{\text {mono }}-P_{\text {mix }}\right) / P_{\text {mono }}$, where $P_{\text {mono }}$ is the number of established sainfoin plants, and $P_{\text {mix }}$ is the number of established sainfoin and nurse plants. Relative competition intensity for the yield was calculated: $\mathrm{RCl}$ yield $=\left[\left(Y_{\text {mix }}-Y_{\text {mono }}\right) / Y_{\text {mix }}\right] * 100$ where $Y_{\text {mono }}$ is the DM yield of sainfoin monoculture, and $\underline{Y}_{\text {mix }}$ is the DM yield of sainfoin and nurse crop mixtures.

\section{4 | Chemical analyses}

Nutritive value of the oven-dried forage samples in the year of establishment was determined for both experiments. Dried, bulk samples were grounded to pass through a 1-mm screen (MF $10 \mathrm{~B}$; IKA werke, USA) and analysed for DM (2001.12) by AOAC methods (2003). The crude protein (CP) concentration of all samples was determined by the Kjeldahl method according to the AOAC (1990; Gerhardt, Vapodest $45 \mathrm{~s}$, with automated distillation and titration, Germany). Neutral detergent fibre (NDF) and acid detergent fibre (ADF) were assayed according to the methods described by Van Soest, And and Lewis (1991) using an Ankom ${ }^{200 / 220}$ Fiber Analyzer (Ankom Technology). The NDF was analysed with the inclusion of a heat stable $\alpha$-amylase and sodium sulphite; both NDF and ADF were expressed inclusive of residual ash. The condensed tannin (CT) content of dried forage subsamples was analysed according to the method of Makkar (2003) and was expressed as tannic acid equivalent.

\section{5 | Statistical analyses}

DM yield, nutritive value and botanical composition from Experiments 1 and 2 were analysed using a linear mixed model, with treatments (nurse crop species, seeding rates) and sampling dates as fixed effects. Blocks were considered to be random effects. Because the weather conditions were dramatically different in the years of establishment, and estimates of variance from two means would be imprecise, experiments were considered to be a fixed effect, representing relatively wet (2014) and dry (2015) years. Initial analyses were performed separately for each experiment and sampling date, to check ANOVA assumptions and identify outliers. For combined analyses across experiments, PROC GLIMMIX in SAS (SAS Institute Inc., 2014) was used to test for homogeneity of variance and to account for heterogeneous variance in the model when it was found to be significant. A repeated measures analysis was used to adjust for correlated errors across sampling dates. Variance components for random effects were estimated by restricted maximum likelihood (REML). The significance of fixed effects was determined with Type $3 F$ tests. A single degree of freedom contrast was used to compare the control treatment (sainfoin monoculture) with the nurse crop mixtures. The six treatments that included nurse crops were analysed as a balanced factorial with two levels of nurse crops (vetch and triticale), three seeding rate levels and the interaction of nurse crops and seeding rates. Differences among treatment means were compared by Fisher's protected least significant difference (LSD) at $\alpha=.05$. Computations were carried out using GENSTAT (Payne et al., 2009) and SAS (SAS Institute Inc., 2014) statistical software.

\section{3 | RESULTS}

\section{1 | Plant populations and competition intensities}

Sainfoin and nurse crop emergence were both significantly affected by the companion nurse crop species, sowing rate and establishment year $(p<.01)$. Averaged across all treatments, the number of sainfoin plants after emergence was lower $(p<.01)$ in Experiment 2 (110 plants $/ \mathrm{m}^{2}$ ) than in Experiment 1 (236 plants $/ \mathrm{m}^{2}$ ) (Figure 1a,b). The number of sainfoin seedlings emerged in sainfoin monoculture (control) was higher $(p<.01)$ than when planted with the nurse crops vetch and triticale (Figure 1a). In general, planting nurse crops at low seeding rates had little impact on sainfoin emergence, whereas the high seeding rates $(90 \mathrm{~kg} / \mathrm{ha}$ ) significantly reduced the number of sainfoin seedlings as compared to the control (Figure 1a). Significant experiment $\times$ nurse crop $(p<.01)$ and experiment $\times$ sowing rate $(p<.01)$ interactions were detected for the nurse crop seedling populations (Figure 1b). This interaction revealed that the numbers of established vetch and triticale plants were lower in Experiment 2 than Experiment 1, but the decline in plant numbers was greater for vetch than triticale, and at higher sowing rates (Figure $1 \mathrm{~b}$ ).

Significant year $\times$ nurse crop $(p<.01)$ and year $\times$ sowing rate $(p<.01)$ interactions were detected for the changes in the plant populations of sainfoin across years in Experiment 1 (Figure 1c). Sainfoin plant numbers in monoculture and sainfoin-vetch plots decreased steadily from 2015 to 2017, while the number of sainfoin plants in sainfoin-triticale plots was first reduced by $19 \%$ in 2016 before it became stable in the summer of 2017. In Experiment 1, sainfoin plant numbers in sainfoin-vetch and sainfoin-triticale plots were reduced at higher sowing rates in 2015, but remained stable in the summer of 2017. In Experiment 2, the total number of sainfoin plants was $10 \%$ lower in 2017 than in 2016 (Figure 1d). Overall, sainfoin plant numbers were lower when planted with triticale than with vetch, and at higher and medium seeding rates than at low seeding rates.

Relative competition intensity $(\mathrm{RCl})$ for the established sainfoin plants was significantly greater $(p<.01)$ when planted with triticale (0.49) than vetch (0.16), and at the higher seeding rates than at lower seeding rates (Table 3 ). However, the $\mathrm{RCl}$ for yield was only affected by the type of the nurse crop $(p<.01)$, with sainfoin-triticale having greater $\mathrm{RCI}$ (78.8) than sainfoin-vetch (39.4). The year of establishment did not affect the $\mathrm{RCl}$ for plant densities and yield. 

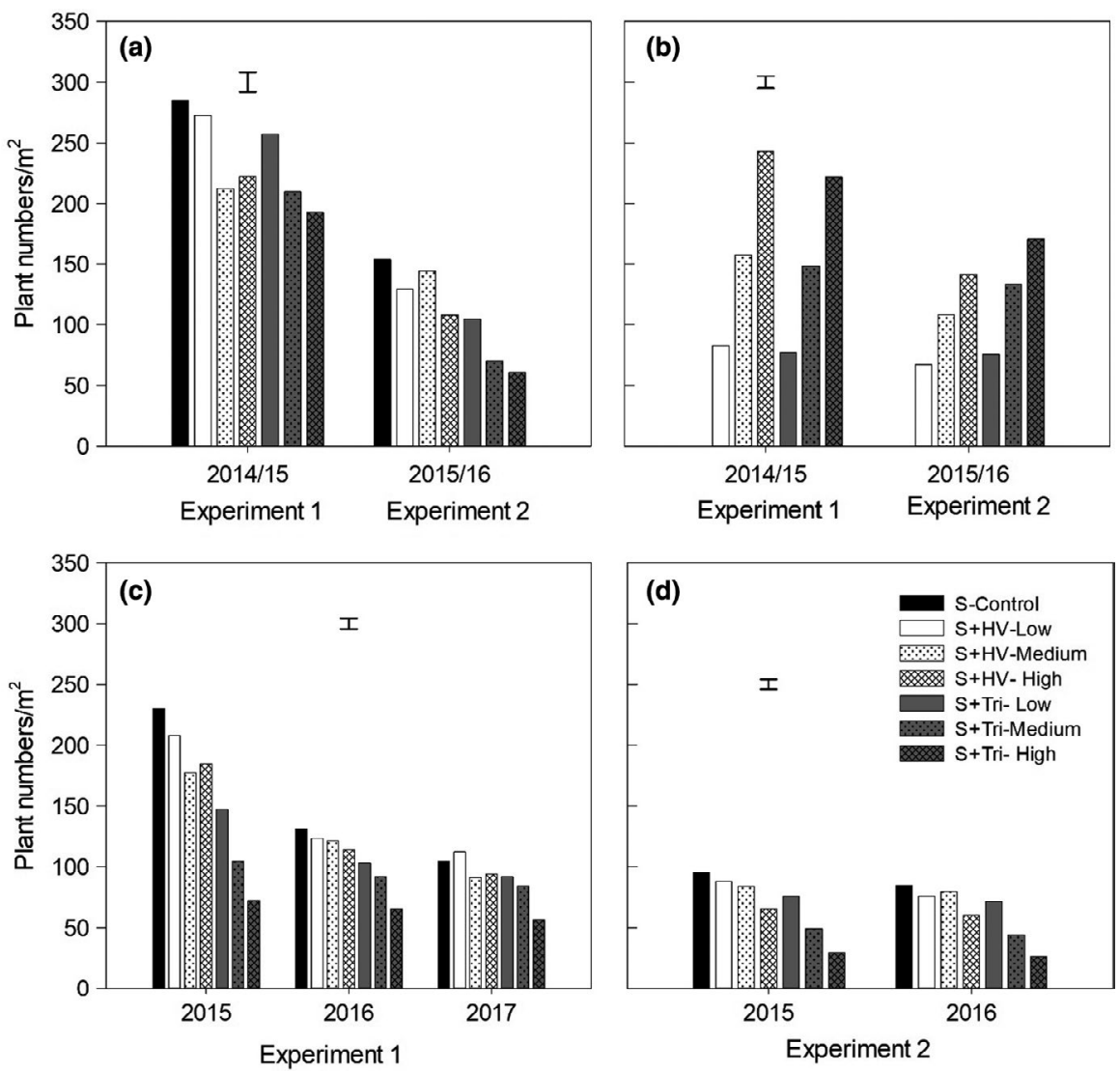

FIGURE 1 Sainfoin (a) and nurse crops (b) plant populations $\left(\mathrm{m}^{-2}\right)$ at emergence, and established sainfoin populations following the year of establishment [(c) Experiment 1 and (d) Experiment 2]. Error bars represent the pooled SE for each treatment

\section{2 | Dry-matter production}

In Experiment 1, sainfoin-vetch mixtures had 1,228 kg/ha greater $(p<.01)$ DM yield than sainfoin monocultures in 2015 (Figure 2a). Planting sainfoin with triticale resulted in greater yields, exceeding $10 \mathrm{t} / \mathrm{ha}$. The subsequent sainfoin DM production in 2016 ranged from 1,590 to $2,170 \mathrm{~kg} / \mathrm{ha}$ and did not differ significantly due to treatments. The DM yield in 2017 was lower $(p<.05)$ in sainfoin plots planted with triticale compared to both the sainfoin monocultures and mixtures with vetch. The seeding rate of the nurse crops did not have any effect on DM yield in the year of establishment nor in the following years.

\begin{tabular}{|c|c|c|c|c|c|c|c|}
\hline \multirow[b]{2}{*}{ Experiment } & \multirow[b]{2}{*}{ Mix } & \multicolumn{3}{|c|}{$\mathrm{RCl}$ plant numbers } & \multicolumn{3}{|c|}{$\mathrm{RCl}$ yield } \\
\hline & & Low & Medium & High & Low & Medium & High \\
\hline \multirow[t]{2}{*}{$2014 / 15$} & $\mathrm{~S}+\mathrm{HV}$ & 0.08 & 0.22 & 0.19 & 37.9 & 46.5 & 31.1 \\
\hline & $S+$ Tri & 0.35 & 0.54 & 0.69 & 79.4 & 78.8 & 81.3 \\
\hline \multirow[t]{2}{*}{$2015 / 16$} & $\mathrm{~S}+\mathrm{HV}$ & 0.06 & 0.08 & 0.32 & 37.2 & 35.2 & 48.8 \\
\hline & $S+$ Tri & 0.20 & 0.48 & 0.67 & 75.7 & 79.5 & 78.3 \\
\hline$P_{\text {Expt }}$ & & & 0.56 & & & 0.99 & \\
\hline$P_{\mathrm{NC}}$ & & & $<0.01$ & & & $<0.01$ & \\
\hline$P_{\mathrm{SR}}$ & & & $<0.01$ & & & 0.76 & \\
\hline$P_{\mathrm{NC} \times \mathrm{SR}}$ & & & 0.15 & & & 0.97 & \\
\hline$P_{\text {Expt } \times \mathrm{NC}}$ & & & 0.52 & & & 0.53 & \\
\hline$P_{\text {Expt } \times \mathrm{SR}}$ & & & 0.33 & & & 0.23 & \\
\hline$P_{\text {Expt } \times \mathrm{NC} \times \mathrm{SR}}$ & & & 0.56 & & & 0.11 & \\
\hline SE (2014/15) & & & 0.06 & & & 4.57 & \\
\hline SE (2015/16) & & & 0.11 & & & 5.68 & \\
\hline
\end{tabular}

TABLE 3 Relative competition intensities for established plant numbers ( $\mathrm{RCl}$ plant numbers) and yield ( $\mathrm{RCl}$ yield) for sainfoin and Hungarian vetch (S + HV) and sainfoin and triticale $(\mathrm{S}+\mathrm{Tri})$ mixtures

Note: The standard errors (SE) apply to each treatment mean in each experiment.

Abbreviations: Expt, Experiment; NC, nurse crop; SR, seeding rate. 
FIGURE 2 DM production of sainfoin monoculture and mixtures with Hungarian vetch and triticale sown at low $(30 \mathrm{~kg} /$ ha) medium (60 kg/ha) and high $(90 \mathrm{~kg} /$ ha) seeding rates for Experiment 1 (a) and Experiment 2 (b). Error bars represent the pooled SE for each treatment

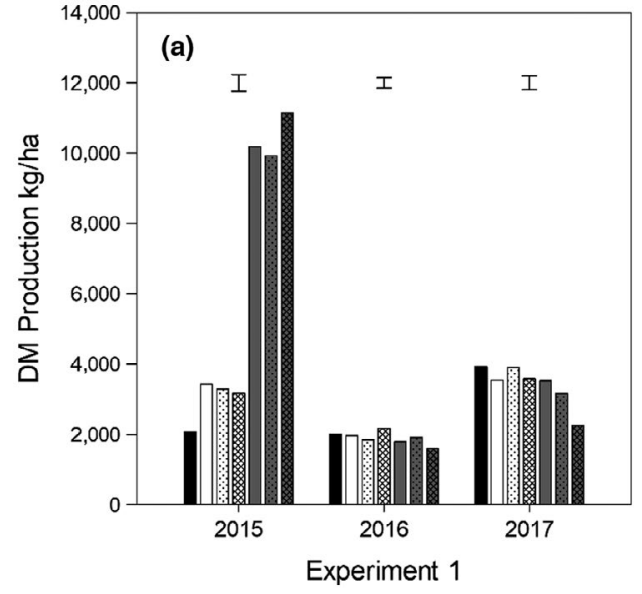

TAB LE 4 Botanical composition of sainfoin, sainfoin-Hungarian vetch $(\mathrm{S}+\mathrm{HV})$ and sainfoin-triticale $(\mathrm{S}+$ Tri) mixtures during the establishment years in Experiment 1 and Experiment 2

\begin{tabular}{|c|c|c|c|c|c|c|c|}
\hline \multirow[b]{2}{*}{ Crops } & \multirow[b]{2}{*}{ SR } & \multicolumn{3}{|c|}{ Experiment 1 (2015) } & \multicolumn{3}{|c|}{ Experiment 2 (2016) } \\
\hline & & \multicolumn{3}{|l|}{ (\%) } & \multicolumn{3}{|l|}{ (\%) } \\
\hline \multirow[t]{2}{*}{ Sainfoin } & Control & 93.0 & - & 7.0 & 83.5 & - & 16.5 \\
\hline & Low & 27.3 & 69.5 & 3.3 & 33.5 & 55.5 & 11.3 \\
\hline $\mathrm{S}+\mathrm{HV}$ & Low & 4.0 & 95.3 & 0.8 & 6.3 & 89.5 & 4.3 \\
\hline \multirow[t]{2}{*}{$S+\operatorname{Tri}$} & Medium & 4.0 & 95.3 & 0.8 & 3.8 & 91.8 & 4.5 \\
\hline & High & 2.0 & 97.5 & 0.5 & 3.5 & 93.0 & 3.5 \\
\hline \multicolumn{2}{|c|}{$P_{\text {Control vs others }}$} & $<0.01$ & - & $<0.01$ & 0.30 & - & 0.28 \\
\hline \multicolumn{2}{|l|}{$S E_{N C \times S R}$} & 4.2 & 4.4 & 0.6 & 3.3 & 3.4 & 2.0 \\
\hline
\end{tabular}

Abbreviations: NC, nurse crop; SR, seeding rate.

In Experiment 2, the sainfoin monocultures had similar a DM yield to sainfoin-vetch mixtures but lower $(p<.01)$ DM yield than sainfointriticale mixtures (Figure $2 b$ ). However, the subsequent DM yield of sainfoin in 2017 was lower $(p<.05)$ for sainfoin that was planted with triticale than for sainfoin monocultures and sainfoin that was planted with vetch in the previous year. As observed in Experiment 1, the seeding rate of the nurse crops in Experiment 2 did not have any effect on DM yield in the year of establishment nor in the following year.

\section{3 | Botanical composition and nutritive value in the year of establishment}

In Experiment 1, sainfoin monocultures had higher $(p<.01)$ weed contents than sainfoin-vetch and triticale mixtures (Table 4). Sainfoin content was less than $5 \%$ when sown with triticale as compared to
21\% when sown with vetch. In Experiment 2, sainfoin content in sainfoin-vetch and sainfoin-triticale mixtures showed a similar trend as in Experiment 1. Weed content of sainfoin monocultures in Experiment 2 exceeded $15 \%$, and this was greater $(p<.01)$ than the weed content in sainfoin-vetch (10\%) and sainfoin-triticale (4\%) mixtures.

In both Experiment 1 and 2, sainfoin monocultures and sainfoin-vetch mixtures had similar CP, NDF and ADF contents (Table 5). Sainfoin-triticale mixtures had lower $(p<.01) \mathrm{CP}$ and ADF, but greater NDF content than sainfoin monocultures and sainfoinvetch mixtures. TDN content of sainfoin mixtures with triticale was greater $(p<.01)$ than sainfoin monocultures in both experiments, but only greater than sainfoin-vetch mixtures in Experiment 1. Condensed tannin content in sainfoin monocultures was greater than in sainfoin-vetch and sainfoin-triticale mixtures. The seeding rate of nurse crops had no significant effect on any nutritive value parameters in either experiment. 
TABLE 5 Nutritive value and condensed tannin contents of sainfoin, sainfoin-Hungarian vetch (S + HV) and sainfoin-triticale (S + Tri) mixtures in Experiment 1 and 2, measured in 2015 and 2016 respectively

\begin{tabular}{|c|c|c|c|c|c|c|c|c|c|c|c|}
\hline Plant & SR & \multicolumn{5}{|c|}{ Experiment 1 (2015) } & \multicolumn{5}{|c|}{ Experiment 2 (2016) } \\
\hline \multirow[t]{2}{*}{ Sainfoin } & Control & 16.6 & 39.7 & 36.9 & 54.6 & 3.65 & 17.8 & 37.7 & 28.6 & 61.8 & 5.44 \\
\hline & Low & 17.0 & 45.0 & 33.5 & 57.2 & 2.67 & 18.9 & 36.2 & 26.4 & 62.5 & 3.51 \\
\hline \multirow{2}{*}{$\mathrm{S}+\mathrm{HV}$} & High & 17.0 & 40.2 & 33.2 & 57.4 & 2.09 & 18.9 & 40.2 & 26.9 & 62.2 & 2.22 \\
\hline & Low & 14.8 & 51.0 & 29.1 & 60.5 & 0.69 & 15.9 & 47.2 & 24.6 & 63.9 & 0.88 \\
\hline \multirow[t]{2}{*}{$S+T r i$} & Medium & 14.3 & 49.5 & 29.0 & 60.6 & 0.72 & 13.6 & 46.1 & 24.0 & 64.3 & 0.86 \\
\hline & High & 15.6 & 48.7 & 28.7 & 60.8 & 0.68 & 15.3 & 43.6 & 25.0 & 63.6 & 0.83 \\
\hline \multicolumn{2}{|l|}{$P_{\text {Control vs others }}$} & 0.34 & $<0.01$ & $<0.01$ & $<0.01$ & $<0.01$ & 0.34 & 0.07 & $<0.01$ & $<0.01$ & $<0.01$ \\
\hline \multicolumn{2}{|l|}{$S E_{N C \times S R}$} & 0.58 & 1.83 & 1.38 & 0.82 & 0.49 & 0.76 & 2.18 & 0.78 & 0.63 & 0.63 \\
\hline
\end{tabular}

Abbreviations: ADF, acid detergent fibre; CP, crude protein; CT, condensed tannins; NC, nurse crop; NDF, neutral detergent fibre; SR, seeding rate; TDN, total digestible nutrients.

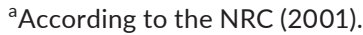

\section{4 | DISCUSSION}

The data did not support our first hypothesis that both nurse crops would increase the total forage production in the year of establishment without compromising the persistence and subsequent production of sainfoin. Sainfoin establishment and persistence were significantly reduced when nurse crops were seeded the highest rates. Our second hypothesis was supported by the data; vetch and triticale differed in their competitiveness against sainfoin, with triticale being more competitive than vetch.

\section{1 | Establishment and persistence}

There is limited information in the literature on the optimum establishment population of sainfoin in terms of persistence and productivity (Bhattarai, Coulman, \& Biligetu, 2016). Even less information is available for sainfoin seeded with annual species used as a nurse crop. The $100 \mathrm{~kg} /$ ha sainfoin seeding rate (typical for the region) used in the present study was similar to $90 \mathrm{~kg} / \mathrm{ha}$ monoculture seeding rate of sainfoin in the UK (Liu et al., 2008), but was much higher than the recommended pasture seeding rate ranging from $14 \mathrm{~kg} /$ ha in drylands of Alberta, Canada (Government of Alberta, 2014) to $50 \mathrm{~kg} / \mathrm{ha}$ in Europe (Koivisto \& Lane, 2001).

Overall, sainfoin establishment within mixtures could be considered successful across the treatments, based on the limited information available from the literature. For instance, in the UK, using varying proportions of meadow fescue (Festuca pratensis Huds.) and perennial ryegrass (Lolium perenne L.) with sainfoin, Liu et al. (2008) observed sainfoin population densities ranging from 36 to 73 plants $/ \mathrm{m}^{2}$. In the present study, even with the highest triticale nurse crop seeding rate $(90 \mathrm{~kg} / \mathrm{ha})$, sainfoin population densities were around 50 plants $/ \mathrm{m}^{2}$. However, DM production under these treatments was significantly reduced compared to sainfoin grown with lower seeding rate nurse crops. The main objective for a farmer would be to obtain maximum amounts of forage from sainfoin mixtures without affecting the monoculture sainfoin productivity during the following two years. Hence, plant population counts in the year of establishment can be used as an indication of the potential for DM production in that year.

Although not directly comparable to sainfoin, using barley (Hordeum vulgare L.) or wheat (Triticum aestivum L.) as nursing crops for lucerne establishment has shown that 30 mature plants $/ \mathrm{m}^{2}$ should be the minimum target plant population (Palmer \& WynnWilliams, 1976). Similarly, in the USA, a lucerne plant density of 43 plants $/ \mathrm{m}^{2}$ was found to be a minimum threshold below which yields decline (Hall, Nelson, Coutts, \& Stout, 2004). The current recommendation in the drylands of Australia is to reduce the cereal nurse crops' seeding rates up to $50 \%$, while increasing lucerne seeding rates by $25 \%$ (Norton \& Koetz, 2014). Using 30 and $40 \mathrm{~kg} / \mathrm{ha}$ seeding densities for barley (nurse crop) and sainfoin respectively, Moyer (1985) reported a reduction of sainfoin stand establishment numbers compared to control. In the present study, triticale only reduced sainfoin establishment, persistence and DM production when sown at the highest seeding rate $(90 \mathrm{~kg} / \mathrm{ha}$ ). In smallholder systems of CWANA, with fragmented lands, higher seeding rates (up to 400 plants $/ \mathrm{m}^{2}$ ) are recommended (Martiniello \& Ciola, 1994).

Our data support the findings by Kölliker et al. (2017) and Malisch et al. (2017). With the appropriate selection of nurse 
crops, sainfoin establishment and productivity can be significantly improved, making this drought-resistant crop more attractive to farmers. It was noteworthy that the seeding rate only affected the relative competition intensities ( $R \mathrm{Cl}$ ) for the number of established plants, while the $\mathrm{RCI}$ for yield appeared unrelated to the seeding rates for both nurse crops. As hypothesized, triticale presented a greater $\mathrm{RCl}$ for plant numbers and yield than vetch, but surprisingly even the lowest seeding rate of triticale had higher $\mathrm{RCl}$ values than the highest seeding rate of vetch. This provided strong evidence that sainfoin can safely be established together with vetch at seeding rates up to $90 \mathrm{~kg} /$ ha and with triticale nurse crops at seeding rates up to $60 \mathrm{~kg} / \mathrm{ha}$.

\section{2 | Dry-matter production}

Large differences in growing season precipitation in Experiment 1 and 2 provided an opportunity to assess the potential of sainfoin establishment and productivity under "good" and "bad" precipitation years. Sainfoin monoculture DM productions of $0.5 \mathrm{t} /$ ha during the establishment year, to $4 \mathrm{t} /$ ha in the third year, were in the range reported by other studies in similar environments (Mohajer, Jafari, \& Taha, 2011; Tosun, 1988), but much lower than DM production reported from more favourable conditions with multiple cuts (Liu et al., 2008; Malisch et al., 2017). It appeared that the productivity of sainfoin monoculture and mixtures was largely dictated by the amount and timing of precipitation, where around $100 \mathrm{~mm}$ less precipitation in Experiment 2 corresponded to up to $60 \%$ less DM production compared to Experiment 1.

The objective of growing sainfoin with nurse crops was to compensate for the low DM productivity of the sainfoin during the establishment year (Häring et al., 2008). As hypothesized, triticale and vetch differed in their competitiveness against sainfoin. When seeded with triticale, first-year forage production exceeded 3 and $10 \mathrm{t} /$ ha in Experiment 2 and 1 respectively, but sainfoin represented less than $10 \%$ of the DM in these mixtures. The advantage of triticale over vetch in terms of DM production was clear in Experiment 1 and less pronounced in Experiment 2. It is well established that mixtures yield higher than sainfoin monoculture, and when grown without nurse crops, weeds may represent up to 98\% of all DM production in sainfoin (Malisch et al., 2017; Moyer, 1985). When the goal of the farmer is to obtain a high amount of forage DM, seeding sainfoin with 30 and $60 \mathrm{~kg} / \mathrm{ha}$ of triticale could be a cost-effective way to optimize forage production while establishing the perennial sainfoin. The results of the study support our hypothesis that planting sainfoin with a nurse crop substantially increased the DM yield in the year of establishment without causing any yield penalties in subsequent years, despite fewer established plants as compared to sainfoin monocultures. The successful establishment of sainfoin sown with a nurse crop, even at high seeding rates, in a "bad" precipitation year highlighted the value of sainfoin and the effectiveness of the use of nurse crops to increase the DM yield while suppressing the weed populations.

\subsection{Nutritive value and secondary metabolite compounds}

One of the key attributes of sainfoin is its high feeding value and production of condensed tannins that help to improve ruminant performance and health (Piluzza, Sulas, \& Bullitta, 2014; Waghorn, 2008). In the present study, sainfoin monocultures or sainfoinvetch mixtures provided forage with higher nutritional value than sainfoin-triticale mixtures as evidenced by greater CP, CT and lower NDF. This indicates that DM production of sainfoin can be increased greatly in the year of establishment without compromising the nutritive value of the forage when it is planted with a "less competitive" forage legume as a nurse crop. It was of note that the nutritive value of the sainfoin and sainfoin-vetch forages were comparable to prime lucerne hay ( $>19 \% \mathrm{CP},<31 \% \mathrm{ADF}$ and $<40 \%$ NDF) (Lacefield, 1998). This supports promotion of sainfoin and vetch mixtures for areas that are marginal for lucerne production without irrigation. In contrast, planting sainfoin with triticale penalized the nutritional value, in part due to the low sainfoin content $(2.0 \%-6.3 \%)$ in the mix. The results revealed that regardless of the rainfall and sowing rate applied in the current study, planting sainfoin with triticale resulted in almost pure triticale forage at harvest. It is probable that reducing the sowing rate of triticale lower than $30 \mathrm{~kg} /$ ha may provide higher sainfoin content in the mixtures. However, this may come at the expense of lower DM yields in the year of establishment than obtained in the current study.

These results on the nutritive value were consistent in both years, with the exception of the CT contents. Overall, the CT concentration obtained in this study was within the range (3.5\%-5\%) reported by Wang et al. (2015) for the primary growth (first harvest). A feature of the results was that the CT content of the forages was greater in Experiment 2 than Experiment 1. This can possibly be attributed to the plant response to environmental conditions, since the accumulation of CT in plant tissues is increased in dry weather or rainfed production systems (Wang et al., 2015). Condensed tannin contents of sainfoin monoculture exceeded $5 \%$ DM in Experiment 2, and this was greater than in sainfoin-vetch and sainfoin-triticale mixtures by $47 \%$ and $84 \%$ respectively. With the exception of the $\mathrm{CT}$ concentration of sainfoin monoculture in Experiment 2, overall the CT concentration of the sainfoin monocultures and mixtures with vetch was lower than the recommended CT content of $5 \%$ for the best feed value effect (Wang et al., 2015).

\section{5 | CONCLUSIONS}

Sainfoin and nurse crop emergence were significantly affected by the nurse crop species, sowing rate and establishment year. Planting nurse crops at high seeding rates reduced the number of sainfoin seedlings as compared to the control, while the use of low seeding rates had little effect on sainfoin establishment. Overall, sainfoin population numbers were lower when planted with triticale than vetch and lower at higher and medium than at low seeding rates. 
The seeding rate of the nurse crops did not affect DM yield in the year of establishment nor in the following years. It appeared that sainfoin monoculture and mixtures' productivity was largely dictated by the amount of precipitation. Even with the highest nurse crop seeding rates, sainfoin was able to establish minimum numbers of plants, but dry-matter productivity suffered when seeded with triticale. This provided strong evidence that sainfoin can safely be established together with vetch at seeding rates up to $90 \mathrm{~kg} / \mathrm{ha}$ and with triticale nurse crops at seeding rates up to $60 \mathrm{~kg} / \mathrm{ha}$. This study showed that with the appropriate selection of nurse crops, sainfoin establishment and productivity can be significantly improved, making this drought-resistant crop attractive for the farmers.

\section{ACKNOWLEDGMENTS}

The authors acknowledge the Australian Centre for International Agricultural Research (ACIAR) for financial support in undertaking this study. The study was conducted as part of mirror trial concept for the "Forage options for smallholder livestock in water-scarce environments of Afghanistan" project (AH/2012/021).

\section{CONFLICT OF INTEREST}

Authors declare no conflict of interest.

\section{ORCID}

Harun Cicek (iD https://orcid.org/0000-0002-4932-3236

Serkan Ates iD https://orcid.org/0000-0001-6825-3248

Mounir Louhaichi iD https://orcid.org/0000-0002-4543-7631

\section{REFERENCES}

Acar, Z., Asci, Ö. Ö., Basaran, U., Ayan, I., \& Mut, H. (2011). Can triticale be used as a companion crop with red clover? Turkish Journal of Agriculture and Forestry, 35(3), 235-245.

Annicchiarico, P., Alami, I. T., Abbas, K., Pecetti, L., Melis, R. A. M., \& Porqueddu, C. (2017). Performance of legume-based annual forage crops in three semi-arid Mediterranean environments. Crop and Pasture Science, 68(11), 932-941. https://doi.org/10.1071/ CP17068

Annicchiarico, P., Barrett, B., Brummer, E. C., Julier, B., \& Marshall, A. H. (2015). Achievements and challenges in improving temperate perennial forage legumes. Critical Reviews in Plant Sciences, 34(1-3), 327-380. https://doi.org/10.1080/07352689.2014.898462

AOAC (2003). Official methods of analysis of AOAC international (17th 2 rev. ed.). Gaithersburg, MD: AOAC.

Ates, S., Feindel, D., El Moneim, A., \& Ryan, J. (2014). Annual forage legumes in dryland agricultural systems of the West Asia and North Africa Regions: Research achievements and future perspective. Grass and Forage Science, 69(1), 17-31. https://doi.org/10.1111/gfs.12074

Ates, S., Norman, H., Ben Salem, H., Nutt, B., \& Cicek, H. (2015). Promising forage options to enhance livestock production in Mediterranean climate agricultural systems. In The proceedings of XXIII international grassland congress, 20 to 24 November, New Delhi, India (pp. 21-29).

Bell, L. W., Moore, A. D., \& Kirkegaard, J. A. (2014). Evolution in croplivestock integration systems that improve farm productivity and environmental performance in Australia. European Journal of Agronomy, 57, 10-20. https://doi.org/10.1016/j.eja.2013.04.007

Bhattarai, S., Coulman, B., \& Biligetu, B. (2016). Sainfoin (Onobrychis viciifolia Scop.): Renewed interest as a forage legume for western Canada. Canadian Journal of Plant Science, 96(5), 748-756.
Chapko, L. B., Brinkman, M. A., \& Albrecht, K. A. (1991). Oat, oat-pea, barley, and barley-pea for forage yield, forage quality, and alfalfa establishment. Journal of Production Agriculture, 4(4), 486-491. https:// doi.org/10.2134/jpa1991.0486

Christiansen, S., Ryan, J., Singh, M., Ates, S., Bahhady, F., Mohamed, K., ... Loss, S. (2015). Potential legume alternatives to fallow and wheat monoculture for Mediterranean environments. Crop and Pasture Science, 66(2), 113-121. https://doi.org/10.1071/CP14063

Cupina, B., Krstic, D., Mikic, A., Eric, P., Vuckovic, S., \& Pejic, B. (2010). The effect of field pea (Pisum sativum L.) companion crop management on red clover (Trifolium pratense L.) establishment and productivity. Turkish Journal of Agriculture and Forestry, 34(4), 275-283.

Davis, A. S., Hill, J. D., Chase, C. A., Johanns, A. M., \& Liebman, M. (2012). Increasing cropping system diversity balances productivity, profitability and environmental health. PLoS ONE, 7, e47149. https://doi. org/10.1371/journal.pone.0047149

Entz, M. H., Baron, V. S., Carr, P. M., Meyer, D. W., Smith, S., \& McCaughey, W. P. (2002). Potential of forages to diversify cropping systems in the Northern Great Plains. Agronomy Journal, 94(2), 240-250. https:// doi.org/10.2134/agronj2002.0240

Foyer, C. H., Lam, H. M., Nguyen, H. T., Siddique, K. H., Varshney, R. K., Colmer, T. D., ... Cooper, J. W. (2016). Neglecting legumes has compromised human health and sustainable food production. Nature Plants, 2(16), 112.

Gan, Y., Hamel, C., O'Donovan, J. T., Cutforth, H., Zentner, R. P., Campbell, C. A., ... Poppy, L. (2015). Diversifying crop rotations with pulses enhances system productivity. Scientific Reports, 5, 14625. https://doi. org/10.1038/srep14625

Government of Alberta (2014). Sainfoin in Alberta. Retrieved from https ://www1.agric.gov.ab.ca/\$Department/deptdocs.nsf/all/aet16 292/\$FILE/sainfoin-in-AB-bulletin-1.pdf

Grace, J. B. (1995). On the measurement of plant competition intensity. Ecology, 76(1), 305-308. https://doi.org/10.2307/1940651

Hall, M. H., Nelson, C. J., Coutts, J. H., \& Stout, R. C. (2004). Effect of seeding rate on alfalfa stand longevity. Agronomy Journal, 96(3), 717722. https://doi.org/10.2134/agronj2004.0717

Hanna, M. R., Kozub, G. C., \& Smoliak, S. (1977). Forage production of sainfoin and alfalfa on dryland in mixed-and alternate-row seedings with three grasses. Canadian Journal of Plant Science, 57(1), 61-70. https://doi.org/10.4141/cjps77-010

Häring, D. A., Scharenberg, A., Heckendorn, F., Dohme, F., Lüscher, A., Maurer, V., ... Hertzberg, H. (2008). Tanniferous forage plants: Agronomic performance, palatability and efficacy against parasitic nematodes in sheep. Renewable Agriculture and Food Systems, 23(1), 19-29. https://doi.org/10.1017/S1742170507002049

IPCC (2014). Climate change 2014: Synthesis report. In Core Writing Team, R. K. Pachauri, \& L. A. Meyer (Eds.), Contribution of working groups I, II and III to the Fifth assessment report of the intergovernmental panel on climate change (p. 151). Geneva, Switzerland: IPCC.

Irani, S., Majidi, M. M., Mirlohi, A., Karami, M., \& Zargar, M. (2015). Response to drought stress in sainfoin: Within and among ecotype variation. Crop Science, 55(5), 1868-1880. https://doi.org/10.2135/ cropsci2014.07.0481

Jafari, A. A., Rasoli, M., Tabaei-Aghdaei, S. R., \& Salehi, P. (2014). Evaluation of herbage yield, agronomic traits and powdery mildew disease in 35 populations of sainfoin (Onobrychis sativa) across 5 environments of Iran. Romanian Agricultural Research, 31, 41-48.

Kazuk, R. W. (2010). An investigation of sainfoin condensed tannin dynamics in manured perennial forage production. M.Sc. Thesis, University of Manitoba, Canada.

Koivisto, J. M., \& Lane, G. P. F. (2001). Sainfoin worth another look. Retrieved from http://www.fao.org/ag/agp/agpc/doc/gbase/addin fo/sainfoin.pdf

Kölliker, R., Kempf, K., Malisch, C. S., \& Lüscher, A. (2017). Promising options for improving performance and proanthocyanidins of the 
forage legume sainfoin (Onobrychis viciifolia Scop.). Euphytica, 213(8), 179. https://doi.org/10.1007/s10681-017-1965-6

Koohafkan, P., \& Stewart, B. A. (2008). Water and cereals in drylands (120 pp). Routledge, London, Sterling, VA: Food and Agriculture Organization (FAO) \& Earthscan.

Küchenmeister, K. (2013). Performance of underutilized forage legumes as an alternative to Trifolium repens under drought stress: Yield, water utilization and nutritive value. Doctoral dissertation, Niedersächsische Staats-und Universitätsbibliothek Göttingen.

Lacefield, G. D. (1998). Alfalfa hay quality makes the difference. Lexington, KY: University of Kentucky, Department of Agronomy AGR-137.

Larbi, A., Hassan, S., Kattash, G., El-Moneim, A. A., Jammal, B., Nabil, H., \& Nakkul, H. (2010). Annual feed legume yield and quality in dryland environments in north-west Syria: 1 . Herbage yield and quality. Animal Feed Science and Technology, 160(3-4), 81-89.

Liu, Z., Lane, G. P. F., \& Davies, W. P. (2008). Establishment and production of common sainfoin (Onobrychis viciifolia Scop.) in the UK. 1. Effects of sowing date and autumn management on establishment and yield. Grass and Forage Science, 63(2), 234-241.

Makkar, H. P. (2003). Quantification of tannins in tree and shrub foliage: A laboratory manual. Dordrecht, The Netherlands: Kluwer Academic Publishers.

Malisch, C. S., Suter, D., Studer, B., \& Lüscher, A. (2017). Multifunctional benefits of sainfoin mixtures: Effects of partner species, sowing density and cutting regime. Grass and Forage Science, 72(4), 794-805. https://doi.org/10.1111/gfs.12278

Martiniello, P., \& Ciola, A. (1994). The effect of agronomic factors on seed and forage production in perennial legumes sainfoin (Onobrychis viciifolia Scop.) and French honeysuckle (Hedysarum coronarium L.). Grass and Forage Science, 49(2), 121-129.

McIntyre, B. D. (2009). Central and West Asia and North Africa (CWANA) report. Washington, DC: Island Press.

Mikić, A., Ćupina, B., Rubiales, D., Mihailović, V., Šarūnaitè, L., Fustec, J., ... Đorđević, V. (2015). Models, developments, and perspectives of mutual legume intercropping. Advances in Agronomy, 130, 337-419). Academic Press.

Mohajer, S., Jafari, A. A., \& Taha, R. M. (2011). Studies on seed and forage yield in 10 populations of sainfoin (Onobrychis saiva) grown as spaced plants and swards. Journal of Food Agriculture \& Environment, 9(1), 222-227.

Moyer, J. R. (1985). Effect of weed control and a companion crop on alfalfa and sainfoin establishment, yields and nutrient composition. Canadian Journal of Plant Science, 65(1), 107-116. https://doi. org/10.4141/cjps85-015

National Research Council (2001). Nutrient requirements of dairy cattle (7th rev ed.). Washington, DC: National Academy Press.

Norton, M. R., \& Koetz, E. A. (2014). Cover cropping and establishment of lucerne-based pastures in a semi-arid zone, mixed-farming system of uniform rainfall distribution. Grass and Forage Science, 69(2), 334347. https://doi.org/10.1111/gfs.12060

Palmer, T. P., \& Wynn-Williams, R. B. (1976). Relationships between density and yield of lucerne. New Zealand Journal of Experimental Agriculture, 4(1), 71-77. https://doi.org/10.1080/03015521.1976.10425847

Payne, R. W., Harding, S. A., Murray, D. A., Soutar, D. M., Baird, D. B., Glaser, A. I., ... Webster, R. (2009). The guide to GenStat release 12, Part 2. Hemel Hempstead: VSN International.

Piluzza, G., Sulas, L., \& Bullitta, S. (2014). Tannins in forage plants and their role in animal husbandry and environmental sustainability: A review. Grass and Forage Science, 69(1), 32-48. https://doi.org/10.1111/ gfs.12053
Porqueddu, C., Ates, S., Louhaichi, M., Kyriazopoulos, A. P., Moreno, G., Pozo, A., ... Nichols, P. G. H. (2016). Grasslands in 'Old World' and 'New World' Mediterranean-climate zones: Past trends, current status and future research priorities. Grass and Forage Science, 71(1), 1-35. https://doi.org/10.1111/gfs.12212

SAS Institute Inc (2014). SAS/STAT® 13.2 user's guide. Cary, NC: SAS Institute Inc.

Sengul,S. (2003). Performance of some forage grasses or legumes and their mixtures under dry land conditions. European Journal of Agronomy, 19(3), 401-409. https://doi.org/10.1016/S1161-0301(02)00132-6

Sheaffer, C. C. (1989). Legume establishment and harvest management in the USA. In G. C. Marten (Ed.), Persistence of forage legumes. Proc. trilateral workshop: ASA, CSSA, and SSSA. 18-22 July 1988, Honolulu, HI (pp. 277-289).

Sölter, U., Hopkins, A., Sitzia, M., Goby, J. P., \& Greef,J. M. (2007). Seasonal changes in herbage mass and nutritive value of a range of grazed legume swards under Mediterranean and cool temperate conditions. Grass and Forage Science, 62(3), 372-388. https://doi.org/10.1111/j.1365-2494.2007.00592.x

Stevovic, V., Stanisavljevic, R., Djukic, D., \& Djurovic, D. (2012). Effect of row spacing on seed and forage yield in sainfoin (Onobrychis viciifolia Scop.) cultivars. Turkish Journal of Agriculture and Forestry, 36(1), 35-44.

Tosun, M. (1988). The effects of different row spaces and phosphorus doses on seed yield and some other agronomical characteristics of sainfoin under irrigated and dry conditions. Doctoral dissertation, Ph.D. thesis. Agricultural Faculty, Ege University, Izmir.

Tufenkci, S., Erman, M., \& Sonmez, F. (2006). Effects of phosphorus and nitrogen applications and Rhizobium inoculation on the yield and nutrient uptake of sainfoin (Onobrychis viciifolia L.) under irrigated conditions in Turkey. New Zealand Journal of Agricultural Research, 49(1), 101-105.

Türkeş, M., Akgündüz, A. S., \& Demirörs, Z. (2009). Drought periods and severity over the Konya Sub-region of the Central Anatolia Region according to the Palmer Drought Index. Coğrafi Bilimler Dergisi, 7(2), 129-144.

Van Soest, P. J., And, R. J. B., \& Lewis, B. A. (1991). Method for dietary fiber, neutral detergent fiber, and nonstarch polysaccharides in relation to animal nutrition. Journal of Dairy Science, 74, 3583-3597.

Waghorn, G. (2008). Beneficial and detrimental effects of dietary condensed tannins for sustainable sheep and goat production-Progress and challenges. Animal Feed Science and Technology, 147(1-3), 116139. https://doi.org/10.1016/j.anifeedsci.2007.09.013

Wang, Y., McAllister, T. A., \& Acharya, S. (2015). Condensed tannins in sainfoin: Composition, concentration, and effects on nutritive and feeding value of sainfoin forage. Crop Science, 55(1), 13-22. https:// doi.org/10.2135/cropsci2014.07.0489

Zander, P., Amjath-Babu, T. S., Preissel, S., Reckling, M., Bues, A., Schläfke, N., ... Watson, C. (2016). Grain legume decline and potential recovery in European agriculture: A review. Agronomy for Sustainable Development, 36(2), 26. https://doi.org/10.1007/s13593-016-0365-y

How to cite this article: Cicek H, Ates S, Ozcan G, et al. Effect of nurse crops and seeding rate on the persistence, productivity and nutritive value of sainfoin in a cereal-based production system. Grass Forage Sci. 2020;75:86-95. https://doi.org/10.1111/gfs.12467 